\title{
A CRITICAL ANALYSIS OF THE PUBLIC SPHERE IN THE DIGITAL AGE: THE CASE OF THE PETROCARIBE CHALLENGE MOVEMENT
}

\author{
Marc-Henry PIERRE*, Mehmet GÜZEL**
}

Received: 30.07.2021 - Accepted: 30.09.2021

Pierre, M. H. and Güzel, M. (2021). A critical analysis of the public sphere in the digital age: The case of the petrocaribe challange movement. Etkileşim, 8, 90-107.

doi: 10.32739/etkilesim.2021.4.8.139

This study complies with research and publication ethics.

\begin{abstract}
While studies that address the relationship between social media and social movements generally use the functionalist paradigm, the critical analysis of the public sphere in the era of distributed media emphasizes the importance of political economy and political communication. Based on the critical political economy analysis of distributed media, this study examined the Twitter-mediated protest "Petrocaribe Challenge" in relation to a possible political public sphere in Haiti. To this end, a qualitative method based on critical discourse analysis was used in the study. Also, 163 tweets purposely selected by the researchers were analyzed. The research findings showed that the Twitter-mediated Petrocaribe Challenge is a political protest with no leadership and a significant lack of online engagement and communication. Besides, the study found that in a political sphere characterized by extreme social inequalities, universal participation is crucial to the formation of a critical public sphere. Although most educated people in Haiti use social media, the majority of Haitians do not have access to these online platforms, which goes against the principles of the public sphere. While the findings of the present study do not allow for generalization, they make up a significant contribution to the critical analysis of social media as a public sphere.
\end{abstract}

Keywords: Petrocaribe challenge, digital media, the public sphere, political communication, political economy.

* Ph.D. Student, Sakarya University, Institute of Social Sciences,

marc-henry.pierre@ogr.sakarya.edu.tr, ORCID ID: 0000-0002-8007-0599

** Assistant Professor/PhD, Sakarya University, Faculty of Communication, mehmetguzel@sakarya.edu.tr, ORCID: 0000-0001-9557-1911

90 | ETKíteşim | Üsküdar Üniversitesi |iletişim Fakültesi |Akademik Dergisi 


\title{
DIJITAL ÇAČDA KAMUSAL ALANIN ELEŞTiREL BIR ANALIZI: PETROCARIBE CHALLENGE HAREKETI ÖRNEC̆i
}

\author{
Marc-Henry PIERRE*, Mehmet GÜZEL**
}

Gönderim Tarihi: 30.07.2021 - Kabul Tarihi:30.09.2021

Pierre, M. H. and Güzel, M. (2021). A critical analysis of the public sphere in the digital age: The case of the petrocaribe challange movement. Etkileşim, 8, 90-107. doi: 10.32739/etkilesim.2021.4.8.139

Bu çalışma araştırma ve yayın etiğine uygun olarak gerçekleştirilmiştir.

\section{Öz}

Sosyal medya ve toplumsal hareketler arasındaki ilişkiyi ele alan araştırmalar genellikle işlevselci paradigmayı kullanırken, dağıtık medya döneminde kamusal alanın eleştirel analizi, ekonomi politiğin ve siyasi iletişimin önemini vurgulamaktadır. Dağıtık medyanın eleştirel ekonomi politik analizinden yola çıkan bu çalışma, Twitter merkezli bir protesto olan "Petrocaribe Challenge"ı Haiti'deki olası bir siyasal kamusal alanla ilişkili olarak analiz etmiştir. Bu amaçla çalışmada, eleştirel söylem analizine dayanan nitel bir yöntem kullanılmıştır. Araştırmacılar tarafından amaçlı olarak seçilen 163 tweet analiz edilmiştir. Araştırma bulguları, Twitter tabanlı Petrocaribe Challenge'ın, liderlikten yoksun, önemli bir katılım ve iletişim eksikliği olan politik bir protesto olduğunu göstermiştir. Ayrıca, çalışma aşırı sosyal eşitsizliklerle karakterize edilen politik bir alanda, evrensel katılımın kritik bir kamusal alanın oluşturulması için çok önemli olduğunu ortaya koymuştur. Haiti'de çoğunlukla eğitimli insanlar sosyal medyaya erişirken, bu durum çevrimiçi etkileşimlerin kamusal alan ilkelerine aykırı bir biçimde nüfusun çoğunluğunun dışarıda kaldığını göstermektedir. Bu çalışmanın, Haiti'deki siyasal kamusal alana dair bulgulardan yola çıkarak makro genellemelere imkan vermese de sosyal medyanın kamusal bir alan olarak eleştirel analizine anlamlı bir katkı sağlayacağı düşünülmektedir.

Anahtar Kelimeler: Petrocaribe challenge, dijital medya, kamusal alan, siyasal iletişim, ekonomi politik.

* Doktora Öğrencisi, Sakarya Üniversitesi, Sosyal Bilimler Enstitüsü, marc-henry.pierre@ogr.sakarya.edu.tr, ORCID ID: 0000-0002-8007-0599

** Doktor Öğretim Üyesi, Sakarya Üniversitesi, illetişim Fakültesi, mehmetguzel@sakarya.edu.tr, ORCID: 0000-0001-9557-1911 


\section{Introduction}

In the constitutional states, political communication circulates between three authorities, which are political power, media, and public opinion (Habermas, 2006: 411-412). These authorities carry out the process of communication in the public sphere through speech acts. Political authority is at the center of the political system, in parties, parliaments, courts, and committees. It creates an institutionalized discourse and negotiation where political agendas, forensic findings, official guidelines, policies, and regulations are decided. As for the media, they make up a wide platform in which public opinion is formed. Public opinion is made of citizens from different sectors of civil society. Thus, the interactions between political power, media, and public opinion constitute an activity of political communication, which takes place in the public sphere under the rule of law. Habermas emphasizes that the public sphere contributes to political legitimacy by producing political discussions of general interest (Habermas, 2006: 411-412). However, in peripheral countries like Haiti, the illusion of democracy is staged by the manipulation of political discussion platforms. Thus, the public sphere is the expression of social contradictions and power relations in a given society. In the capitalistic relations of production, the public sphere serves the interests of capital to the detriment of public opinion.

The emergence of social media has changed the dynamics of power relations between citizens and the state. Based on utopian technological determinism, social media makes up a critical platform for the masses. In their book Mediactivism, Cardon and Granjon (2010) stress that the masses are liberated through social media. The citizen on social networks speaks without being invited. He unabashedly reveals himself to create new social bonds. They also produce information without relying on others. They define the subjects they want to discuss (Cardon and Granjon, 2010: 11). In the same vein, Johannessen (2013) regards social media as a public sphere that allows rational discussion and increases knowledge on how to establish areas that facilitate negotiation. This approach to social media as a public sphere is one-dimensional as it emphasizes political communication while ignoring the political economy of social media. Habermas (1989) argues that political communication and political economy are two main aspects of the public sphere. The political economy of social media draws attention to capital and to those who are exploited by it. Thus, mediated communication lacks the defining features of deliberation and may contribute to a generalized alienation of citizens from politics (Habermas, 2006: 414). Based on these two dimensions of public space, Fuchs (2014) suggests a dialectical analysis of technology and society. This allows us to see the causal relationship between media and society as multidimensional and complex: a medium has multiple, at least two potential effects on society and on social systems that may contradict each other.

In his analysis of the 2011 Egyptian revolution, Fuchs warns against the essentialist role attributed to social media. According to Fuchs, instead of

92 | ETKíleşim | Yıl 4|Sayı 8| Ekim 2021 
causing revolutions and social change, social media rather makes up a mirror of the power structures and models of exploitation of contemporary society in which capitalist interests predominantly shape the Internet (Fuchs, 2014: 102). In the context of Haiti, the reconstruction of social media as a public sphere falls within the dialectical approach. Indeed, a social movement called "Petrocaribe Challenge" started on Twitter in August 2018. On August 14, 2018, Gilbert Mirabeau, a Haitian filmmaker, posted on Twitter a photo of himself blindfolded, holding a piece of cardboard on which could be read the following question in Haitian Creole: "Kot Kòb Petwo Karibe $A^{1 ?}$ ?". The tweet carried thousands of retweets and comments. Since then, riots demanding the impeachment of the Haitian president have taken place in Haiti and Haitian communities living abroad. This popular movement took place in the sphere of social media and calls for structural transformation in the Haitian political system.

The Petrocaribe Challenge movement questions the accountability of the Haitian political authorities. The movement started as a demand for accountability as regards the Petrocaribe fund, then turned into a call for a complete change in the system. Based on the assumption that the public sphere makes up a platform characterized by political communication and the political economy, this paper addresses two heuristic questions relating to the case of Haiti: How does the Twitter-mediated Petrocaribe Challenge relate to the political public sphere? What are the implications of internetmediated political actions for democracy? This study aims to reconstruct the concept of the public sphere in the context of the Twiter-mediated movement Petrocaribe Challenge. The study aims to assess the concept of visibility on Twitter and the power relations behind such visibility. Based on a critical analysis of the political economy of Twitter, this paper aims to reconstruct Habermas' concept of the public sphere in the Haitian political sphere.

\section{Selective Literature related to Social media and The Public Sphere}

Although various studies have already addressed the public sphere in the

${ }^{1}$ In English: "Where is the Petrocaribe Fund?" Petrocaribe is an alliance between the Caribbean countries and Venezuela, the largest exporter of Latin American crude oil, allowing them to buy oil from the latter on preferential terms of payment. This alliance was created in June 2005 and currently includes 18 countries. The savings from this agreement were meant to finance sustainable social projects and strategic investments to help develop the poorest country in the Western Hemisphere. During the summer of 2018, many young people mobilized via social media behind the hashtag \#PetrocaribeChallenge, to organize events and sit-ins in Port-au-Prince. Objective: to demand an audit. Gradually, the Haitian diaspora demands accountability in several megacities around the world: in New York, Montreal, Miami or Paris. The hashtag used everywhere is "where is the Petrocaribe fund?" The mobilization around the "Petrocaribe affair", has turned into a mass demonstration since February 7, 2019, requesting not only the resignation of the President of the Republic but also a change of system. 
age of social media, they mostly focus on social media as a sphere that allows political communication. Thus, the critical political economy which questions the property and the control of the content shared on social media is frequently overlooked. In a study on online political communication in Norway, Johannessen (2013) addresses social media as a public sphere. In the context of low voter turnout, low political participation, and lack of interest in politics, the study revealed that social media is a tool that can help regain political participation through rational discussions. The research findings showed that social media is a complex socio-technical phenomenon whose use depends on technical and cultural factors. Also, it was revealed that despite their complexity, social media can be used to increase political participation, thereby collective deliberation. However, the study overlooks factors like property and control which play a major role in the process of meaning construction through social media. In the same perspective, DahlbergGrundberg (2016) explores the geographic implications of using digital media for political activism. Based on semi-structured interviews, content analysis, and social media analysis, the study examines four social movements as four case studies. The findings showed that social media played a positive role in the transnationalization of the protests.

González (2016) analyzes the use of social networks in the context of new social movements for peace in Mexico. The study examines how social movements have been theoretically transformed to contribute to the discussion on the role of new communication technologies in redefining social movements and their potential to transform traditional political practices. The study also addresses the potential power of social media to expand political participation and influence political decisions. The results showed that social movements for peace in Mexico contribute to the creation of communication strategies to create a greater community of alliances and solidarity. The results also demonstrated that social media represent a platform allowing activists to choose and build their own stories.

In his study on social media and social movements, Adamoli (2012) critically analyzes the massive use of Facebook to advocate for food activism. The study combines three closely related theoretical perspectives. First, the study examines the influence of Facebook through Habermas' concept of the public sphere by focusing on food activism in the United States. Second, Castells' network analysis was used to analyze the impact of virtual relationships on online and offline travel. Third, the study draws on leadership theory to understand how it is manifested on Facebook. The results showed that while Facebook has privacy issues, its strength lies in its functionality to reach heterogeneous networks to build communities.

Pierre-Louis (2012) suggests a hermeneutic analysis of political communication and the public sphere in Haiti. Based on Habermas' theory of communicative action, the study makes up an analysis of the speech acts of

94 | ETKíleşim | Yıl 4|Sayı 8| Ekim 2021 
two political radio programs in which politicians speak regularly. The research aimed to address the possible relationship between Haitian political discourse and Habermas' concept of the public sphere. The results showed that the Haitian political public sphere is characterized by manipulation and populism. Therefore, unlike Habermas' communicative action, Haitian political discourse is an instrumental action. Pierre-Louis (2012) concludes that political discourse characterized by manipulation is an obstacle to collective deliberation.

The existing literature views social media as a platform that enables political participation and strengthens social movements. This study subscribes to the idea that social media somewhat changes the dynamics of human communication. However, the current analysis aims to address the inequalities hidden behind the lack of access to social media. This paper assumes that poor access to social media sustains unbalanced power relations and hinders a critical public sphere.

In the public sphere theory, Habermas analyzes the degeneration of the bourgeois public sphere with the emergence of a critical public sphere capable of judging the actions of political power. The public sphere makes up a network of content, positions, and ideas. Thus, communication flows are filtered and synthesized to focus on public opinion, grouped according to a specific theme (Habermas, 1997: 60). Habermas attributes a central role to rational discussions in the political organization of society. Relying on popular sovereignty as the procedure, Habermas (1997) introduces the concept of the political public sphere as the core of a theory of democracy. Hence, public debates make up a principle of legitimacy disseminated by the public sphere. In the present study, the concept of the public sphere refers to the political interactions that address problems of general interest.

According to Kaplan (2014), social media is defined as a group of internetbased applications that are built on the ideological and technological foundations of Web 2.0 and enable the creation and modification of usergenerated content. Social media is generally analyzed within a functionalist or critical approach. The functionalist approach regards social media from the perspective of use and gratifications. Thus, Caplan et al. (2007) argue that communication technologies are used for personal, educational, and commercial reasons. Therefore, the user of social media generally seeks information, social connection, and entertainment (Caplan et al, 2007: 42). In contrast, the critical approach regards social media as platforms that sustain power relations and reduce popular resistance. The following section discusses the critical political economy of the media.

\section{The Critical Political Economy of the Media}

The present paper uses the critical political economy of the media, which is rooted in the critical theory of the Frankfurt School. Adorno's analysis 
of the culture industry holds that late capitalism turns media products into light entertainment which eventually benefits the large corporations (Adorno, 1964: 13). It is generally admitted that the political economy of communication appeared in the 1960s and 1970s (Miège, 2004: 47). However, despite the contributions of a few important authors, there is no significant study covering all the theoretical approaches to the political economy of media and communication. Some theorists hold the idea of the political economy of mass communication (Murdock and Golding, 1973; Garnham, 1990). Some others opt for the political economy of political communication (Bouquillion and Combès, 2007; Wasko, 2014; Mosco, 2009). Some others claim the political economy of the media (Hardy, 2014; Winseck and Jin, 2012). Seeking to unify these approaches, Curran (2014) argues the critical stance of these theories makes up their common denominator.

Mosco (2009) defines political economy as the study of social relations, in particular power relations. These power relations constitute the production, distribution, and consumption of resources, including the resources of mutual communication. The political economy of communication constitutes a social exchange of meaning, whose result is a sign of a social relationship. From this point of view, communication is more than a transfer of data or information; it is the social production of meaning that makes relationships possible. Thus, the political economy focuses on the social forces that contribute to the formation of communication channels and the range of messages conveyed through these channels (Mosco, 2009: 2). Therefore, communication is a socially constructed process. According to Herman and Chomsky (1988), the political economy analyzes information produced by mass media as a means of generating consent. From this perspective, advertising competition increased and the boundaries between the editorial and advertising sections are weakened. Thus, media content is controlled by capital, often transnational capital. In this sense, Herman and Chomsky (1988) point out that media editorial staff has been integrated more broadly into international institutional empires.

The authors mentioned above, although critical, address the political economy of the media through the binomial of base and superstructure. Wittel (2012) stresses that in the age of mass communication, the political economy of the media had limited interest in Marxist concepts. This academic field referred mainly to Marx's concept of base and superstructure to analyze the relationship between ownership of the means of production and questions relating to media content, ideology, manipulation, power, and democracy (Wittel, 2012). According to Wittel, the reason for this economic reductionism is that technologies and means of production were expensive in the age of mass communication. However, digital technologies have created a fundamentally different media environment. While in the era of mass media ownership of the means of production referred exclusively to the ownership of the media content, in the age of distributed media, the concept of ownership extends to 
that of connectivity. The analysis of the media content is no more limited to the binominal of base and superstructure; it is rather extended to concepts such as ownership, network, and platforms that allow users to socialize, communicate and collaborate. The analysis of the media content is not only about meaning and representation, but also about controlling people's online interactions, ultimately favoring certain forms of sociability and subjectivity (Wittel, 2012: 318). Wittel suggests a critical analysis of distributed media that involves the concepts of work, value, property, and struggle. He stresses that while social media does not cause revolutions and social movements, it strengthens them. Based on Wittel's approach to distributed media, this study aims to reconstruct the concepts of ownership, value, and struggle in the context of the Twitter-mediated Petrocaribe Challenge movement.

Similarly, Fuchs (2014) suggests a critical political economy that focuses on the power relations behind social media. Based on the Marxist political economy, Fuchs highlights four fundamental parameters of his critical analysis: history, social integrity, moral philosophy, and praxis. The critical analysis deals with issues of power. Power belongs to those who control society, make important decisions, and set standards, rules, and dominant values. Large corporations colonize social media and dominate its attention economy (Fuchs, 2014: 102). According to Fuchs, who uses social media, what social media is used for, and what people talk about on social media are questions that obscure the power relations associated with the use of social media. It is consequently more meaningful to ask who benefits and who is the victim of the use of social media. Based on Habermas' theory of the public sphere, Fuchs suggests a critical analysis of social media that includes both the analysis of political communication and the political economy. The political economy analysis addresses factors like ownership, censorship, exclusion, and production of political content. The analytical grid of political communication includes factors like universal access, independence, and quality of political debates.

\section{Aim and Methodology}

In this study, the qualitative method was used. According to Creswell (2012), the qualitative research method studies a problem and develops a detailed understanding of a central phenomenon. The qualitative research method has a hermeneutic dimension that allows the researcher to interpret the meaning behind a text. The qualitative method used in this paper falls within the interpretive paradigm. In such an approach, the researcher is part and parcel of the phenomenon under study, unlike the positivist approach which claims that there is an objective distance between the researcher and the problem being addressed. 


\section{Aim and significance of research}

This study aims to reconstruct the concept of the public sphere in the context of the Twitter-mediated Petrocaribe Challenge in Haiti. Thus, the paper aims to assess the concept of visibility on Twitter and the power relations behind such visibility. The academic significance of this work stems from the lack of studies that address the Haitian political public sphere in the context of social media.

\section{Research questions}

The research questions stem from the gap in the existing literature. The present paper aims to extend the critical analysis of the public sphere by raising two heuristic questions: How does the Twitter-mediated Petrocaribe Challenge relate to the political public sphere? What are the implications of internet-mediated political actions for democracy?

\section{Scope of research and sampling}

The scope of the research includes all the tweets with the hashtags related to the Petrocaribe Challenge. According to Giroux and Tremblay (2009), the research sample is determined by the researcher, and the nature of the units of analysis is determined by the objectives of the research (Giroud and Tremblay, 2009: 198). The objectives of the paper are to establish the relationship between the Petrocaribe challenge movement and the public sphere, gauge the political economy of the movement, and assess the dimension of political communication of the selected tweets. The sample of this study consists of 163 tweets on the Petrocaribe Challenge movement selected by the researcher.

\section{Data collection technique}

The units of analysis for this study were selected by the researcher from the Twitter accounts of political activists using a hashtag related to the Petrocaribe Challenge.

\section{Data analysis technique}

In this study, a qualitative method including qualitative content analysis and critical discourse analysis was used. According to Berelson (1952), content analysis is a research technique that addresses the manifest content of speech acts. Nevertheless, content analysis is limited as it fails to decipher the latent meaning behind the speech acts. Therefore, the study uses the discourse analysis suggested by Van Dijk (1993) who views media content as discourse. According to Van Dijk, discourse analysis combines discourse, attitudes of

98 | ETKíleşim | Yıl 4|Sayı 8| Ekim 2021 
knowledge, ideologies, and the power with which other social representations are formed. Similarly, Charaudeau (2005) underlines that political discourse constitutes the mask of power. Political discourse is characterized by its power to the masses that think and act, in other words, its power to influence and manipulate the masses (Charaudeau, 2005: 43).

\section{Research findings}

This study aimed to analyze the Twitter-based Petrocaribe Challenge movement with respect to the concept of the public sphere. Using a qualitative methodology based on critical discourse analysis, the study examined 163 tweets downloaded from https://www.vicinitas.io/ (period: December 28, 2019 - January 04, 2020). The researcher selected tweets with the hashtag \#KotKobPetwoKaribeA. Regarding the research questions, this article aimed to assess the dimensions of political communication and the political economy of the selected tweets. Table 1 and Table 2 provide a visual representation of the general results. The presentation of the research findings is followed by critical discourse analysis of these findings.

Table 1. Level of information and communication of tweets relating to the Petrocaribe Challenge

\begin{tabular}{|c|c|}
\hline Hashtag & \#KobKobPetwoKaribeA \\
\hline Number of Tweets & 163 \\
\hline Time period & 28 December 2019 - 4 January 2020 \\
\hline Comments & $2.4 \%$ \\
\hline Retweets & $79.8 \%$ \\
\hline Information & $17.8 \%$ \\
\hline French & $75.5 \%$ \\
\hline Haitian Creole & $24.5 \%$ \\
\hline
\end{tabular}

The findings showed that the retweets account for about $80 \%$ of all the hashtags selected, with a low level of $2.4 \%$ of comments. Fuchs (2012) regards retweets as information. From this perspective, information makes up an overall level of $87.6 \%$ of the tweets selected. According to McQuail (2010), communication may refer to a one-way process (information) or a two-way process (interaction). In this regard, there was real or symbolic interaction in all of the selected tweets. The findings also revealed that French makes up $75.5 \%$ of the languages used in the tweets. Only $24.5 \%$ of the tweets used Haitian Creole. The research findings subscribe to Fuchs' (2012) understanding of Twitter communication, which consists primarily of one-way comments. The section below presents the main themes covered in the tweets selected. 
Table 2. Themes observed in the selected tweets

\begin{tabular}{|c|l|c|}
\hline Themes & \multicolumn{1}{|c|}{ Examples } & $\%$ \\
\hline $\begin{array}{c}\text { Denunciation } \\
\text { of injustice }\end{array}$ & $\begin{array}{l}\text { @ Haitian police continue to repress anti- } \\
\text { corruption activists as anti-government protests } \\
\text { continue. }\end{array}$ & $24.1 \%$ \\
\hline $\begin{array}{c}\text { Call to } \\
\text { rebellion }\end{array}$ & $\begin{array}{l}\text { We are rebelling against the system. We shall } \\
\text { win. \#WherelsThePetocaribeFund? } \\
\text { No intimidation or any kind of dictatorship will } \\
\text { silence us. }\end{array}$ & $18.4 \%$ \\
\hline Accusation & $\begin{array}{l}\text { We must end corruption in Haiti. @moisejovenel, } \\
\text { the first of the bribers and @martinejmoise, } \\
\text { his accomplice. If we are to continue as a } \\
\text { country, the Petrocaribe affair must be our new } \\
\text { direction. \#WherelsThePetocaribeFund? }\end{array}$ & $34.8 \%$ \\
\hline Resistance and \\
persistence & $\begin{array}{l}\text { We'll stay focused. } \\
\text { \#WherelsThePetocaribeFund? } \\
\text { \#WherelsThePetocaribeFund? The irritating yet } \\
\text { relevant question. } \\
\text { As a reminder, @martinejmoise @moisejovenel, } \\
\text { we are still waiting and we are running out of } \\
\text { patience. } \\
\text { No intimidation or any kind of dictatorship will } \\
\text { silence us. } \\
\text { \#WherelsThePetocaribeFund? }\end{array}$ & $22.7 \%$ \\
\hline
\end{tabular}

As shown in Table 2, the main themes expressed in the tweets are corruption, accusation, rebellion, and resistance. Accusation makes the most repeated theme with $34.8 \%$ of tweets, followed by "denunciation of injustice" with $24.1 \%$, "resistance and persistence" with $22.7 \%$, and "call to rebellion" with $18.4 \%$ of the selected tweets. In the tweet below: "We must end the corruption in Haiti, @moisejovenel, the first of the bribers and @ martinejmoise, his accomplice", Haitian President Jovenel Moise and his wife Martine Moise were accused of bribery and corruption. The president and his wife were identified in the tweet, but they did not respond to it. The Petrocaribe movement was also described as a rebellion against the government and its allies: "Haitian police continue to repress anti-corruption activists as anti-government protests continue". The findings also revealed that the Petrocaribe challenge makes up a movement of resistance and persistence. The resistance and persistence of the protesters are expressed 
in the following tweets: "We will not focus", "We are still waiting and we are running out of patience", "Where is the Petrocaribe fund?", "The irritating yet relevant question". The resistance and the anger of the protesters expressed in the tweet are directed towards the President of Haiti.

\section{Discussion: Critical Discourse Analysis of the Research Findings}

The content analysis of the Petrocaribe Challenge movement revealed four main themes addressed by the protesters in their tweets. These themes are "denunciation of injustice", "call to rebellion", "accusation", and "resistance and persistence". The present section makes up a critical analysis of the findings. Here, the findings are regarded as a discourse. According to Van Dijk (1993), critical discourse analysis makes up the analysis of power relations as discourse contributes to the reproduction of domination.

The denunciation of injustice by the protesters exposed the repressive power relations between the State and civilians through the Police. Thus, the Police which violently repressed the protests, are regarded by the protesters as a repressive state apparatus. Also, the Petrocaribe Challenge showed the antagonistic relations between internal forces in a peripheral state like Haiti. Given that the Petrocaribe fund came from Venezuela, it creates internal tensions among Haitians who regard Venezuela as a friendly nation and those who seek political approval from the United States of America. The fact that the Haitian government always felt comfortable despite the street protests and riots illustrates such approval. It should be reminded that the Petrocaribe Challenge took place in the context of a tense relationship between Venezuela and the United States of America. In a context of legitimate repression, the protesters resort to Twitter to make their voices heard.

Another indicator of the antagonistic relationship between the State and the citizens was revealed through tweets that accused the president of Haiti, his wife, and other accomplices of squandering the Petrocaribe fund. These tweets claimed that the fund was received in the name of the citizens yet used by government officials. They also revealed the relationship of distrust between the Haitian government and the citizens. Thus, accusing the government of squandering the Petrocaribe fund and denouncing injustice make up two themes closely intertwined. However, asking for the trial of the Petrocaribe fund while accusing the government officials of squandering this fund seems like an oxymoron as the Haitian judicial apparatus is controlled by the government. Because of this, the protesters called out the citizens to take to the streets. The theme "call to rebellion" revealed several tweets that incite the citizens to rebellion: "we are rebelling against the system". In the protesters' tweets, the concept of the system is understood as a system of injustice and repression. Considering this system, the protesters make 
demonstrations and cling to the hope of change. For the protesters, the effective way to overcome the system of repression is through resistance. One tweet says: "no intimidation or any kind of dictatorship will silence us". From such a perspective, the Petrocaribe Challenge movement shifted from asking for accountability to asking for the resignation of the Haitian president, then from asking for the resignation of the president to requiring a system change. These shifts resulted from the importance of the ground gained by the protesters throughout their movement. This shows that the protesters' tweets along with the street demonstrations make up an effective strategy of political communication. Nevertheless, how much does this political communication contribute to the formation of a political public sphere in Haiti?

Fuchs (2012) suggests that the analysis of the public sphere includes the critical political economy and political communication. In this paper, the political economy of the Petrocaribe Challenge was conducted first. Secondly, the analysis of the Petrocaribe challenge as political communication was performed. The critical political economy Petrocaribe challenge reconstructed the concepts of ownership, political censorship, exclusion, and content production. The analysis of political communication addressed the concepts of universal access, media independence, and political debate

The political economy of the Petrocaribe Challenge revealed a movement without leadership. Marx (1970) insists on the importance of revolutionary consciousness and revolutionary leadership for the achievement of a revolution. The lack of leadership in the Petrocaribe movement stems from the protesters' distrust of traditional politicians who have always exploited popular riots to their interests. Besides, the absence of revolutionary direction stems from the social contradictions that seal the Haitian society. The subjectivity of the actors outweighs the intersubjectivity among them. Habermas (2006) emphasizes the role of intersubjectivity, which makes up rational discussions that lead to praxis. When a social movement becomes praxis, it carries the dimensions necessary for a revolution.

Regarding censorship, there are no legal restrictions on Internet access in Haiti. Regarding the concept of ownership, the movement used Twitter as a means of communication. Fuchs (2012) regards Twitter as a platform that favors capital accumulation. Twitter sustains its imbalanced power relations through asymmetric visibility. Haiti owes the Petrocaribe fund to Venezuela, which is considered one of Haiti's best political allies. However, in January 2019, the United States had Haiti's support to vote against a second term for Venezuelan President, Nicolas Maduro. In return, the United States showed its support for the current Haitian government. They even threatened to deny visas for some Haitian opposition leaders. American support for the Haitian president is an expression of how power and capital manipulate democracy.

102 | ETKiLeşim |Yıl 4 |Sayı 8| Ekim 2021 
Unlike Adamoli's (2012) study, which praises social media as an effective platform for political activism, the current analysis supports Morozov's (2009) view of online activism as a lack of social participation. As a result, the political economy of the Petrocaribe Challenge revealed a movement without leadership, thereby not strong enough to face capital that eventually dictates the meaning and direction of online interactions. Considering that Twitter is a profit-driven platform, they do not have much to gain from social movements that aim to overthrow the dominant social order.

The second dimension of the analysis of the public sphere refers to political communication as an interactive process. The analysis of political communication questions universal access, the independence of the media used, and the quality of political debate. Regarding this study, the degree of political communication of the Petrocaribe movement is rather low. Thus, the Petrocaribe movement sustains the idea that Twitter is an elitist platform. The selected data showed that French was used in more than $75 \%$ of the selected tweets. While Haitian Creole is the mother tongue of all Haitians, only $5 \%$ of the population is fluent in French. The use of French refers to the exclusion of those who do not speak French. Unlike Johannessen (2013), who views social media as a tool that can help regain political participation, this study argues that social media reinforces social inequalities between educated and uneducated citizens. The French language is a legacy of Haiti's colonial past. Being the language of the colonist, French is regarded as an indicator of social status and social differentiation in Haiti. From the perspective of the public sphere, $5 \%$ of the population cannot deliberate collectively. On the contrary, the absence of the majority of the population in online discussions can only reproduce the bourgeois public sphere.

Another condition for effective political communication in the public sphere is universal access to the means of communication. According to CONATEL (2016), Internet penetration in Haiti reached 13\% in 2016, with 1,5 million users. Thus, limited internet access creates an obstacle to the formation of a political public sphere on social media. Unlike the existing literature that highlights the importance of social media in empowering social movements, the critical analysis of the Petrocaribe Challenge revealed a lack of access and participation in internet-mediated political interactions. Habermas stresses that universal access and participation make up fundamental conditions for the public sphere. The critical analysis of the Petrocaribe challenge revealed low access to social media and a lack of political interactions. Besides, the absence of leadership denotes a lack of consensus among the protesters. Consensus makes up the ultimate goal of the discussions that occur in the public sphere. Lack of leadership often causes popular uprisings to be exploited by political discourse. Pierre-Louis (2012) stresses that populist political rhetoric is an obstacle to the formation of the public sphere in Haiti's political environment. 
Despite the street riots that followed the first tweet, the present study revealed that Twitter does not foster social movements.

\section{Conclusion}

This study analyzed the Twitter-based Petrocaribe Challenge movement in the context of Habermas' concept of the public sphere. From a critical point of view, the analysis of the public sphere includes the political economy and political communication. The political economy of the Petrocaribe stems from Twitter's political economy. Twitter is a profit-oriented microblog used mostly for entertainment and information. Thus, Twitter's audience makes up both consumers and commodities to the benefit of capital. Access to Twitter is based on education level and access to the Internet. In a country like Haiti, where internet access is very low, social media fails to be a channel that enables intersubjective actions. The political economy of the Petrocaribe Challenge revealed that Twitter is an elitist platform. The critical analysis of the Twitterbased Petrocaribe Challenge revealed a movement that excluded the majority of the Haitian population as most of the selected tweets are written in French. Petrocaribe Challenge is also characterized by a lack of communication. Despite the political content of the tweets, the lack of comments and reactions to the tweets hinders communication between protesters.

The present analysis holds that the Petrocaribe Challenge is a Twittermediated political movement that does not meet the criteria of the political public sphere. The study subscribes to the critical view of Twitter as a bourgeois platform that goes against the principles of the critical public sphere. However, the reconstruction of the selected tweets showed that Twitter makes up an information channel that allowed the protesters to raise awareness about the movement. Nonetheless, social media protests cannot lead to a system change unless they are expressed in a consistent revolutionary project. In the case of the Petrocaribe Challenge, it can be assumed that the majority of protesters who took to the streets do not use Twitter, although the movement started on Twitter. Twitter's unpopular character goes against the principles of a social movement. Although the use of Twitter helped increase awareness of the problems raised by the protesters, this platform mostly fosters passive forms of activism. Although social media can strengthen popular protests, revolutions cannot be carried out without revolutionary consciousness and revolutionary direction. The political use of Twitter in the context of Haiti reflects exclusion and lack of access. Admittedly, the Petrocaribe Challenge constitutes a movement geared towards a system change in Haiti, not for visibility on social media. However, a system change cannot occur on Twitter, but in social struggles for justice and equality. Social justice and equality imply universal access to education and all social rights. Thus, social awareness and

104| ETKileşim |Yıl 4 |Sayı 8| Ekim 2021 
political participation are crucial in addressing the social contradictions that perpetuate a highly unequal Haitian society. The formation of the Haitian political public sphere requires rational discussions about exclusion, social injustice, and corruption.

Without being a breakthrough in the field of political communication, this paper subscribes to the critical analysis of the public sphere in the era of social media. Although limited in both scope and time, the study makes up a prolegomenon to further analyses of the public sphere in Haiti. Given the complexity of the Petrocaribe Challenge as a social phenomenon, future research should use a larger sample size. Besides, further investigations should include mixed methods of social network analysis, surveys, and interviews to increase the generalizability of the findings. Also, since most social scientists subscribe to a functionalist approach to social media, future research should include the critical political economy and political communication in the analysis of the public sphere. Finally, as social phenomena occur in different spaces and times, researchers should pay attention to the cultural, political, and economic contexts in which online platforms are used.

\section{References}

Adamoli, G. C. E. (2012). Social media and social movements: A critical analysis of audience's use of Facebook to advocate food activism offline (Unpublished PhD thesis). Florida State University, USA. http://diginole.lib.fsu.edu/islandora/ object/Fsu\%3A183217.

Adorno, T. W. (1964). L'industrie culturelle. Communications, 3(3), 12-18.

Berelson, B. (1952). Content analysis in communication research. Michigan: Free Press

Bouquillion, P. and Combès, Y. (2007). Les industries de la culture et de la communication en mutation. Paris: Éditions L'Harmattan.

Caplan, S. E., Perse E. M. and Gennaria, J. E. (2007). Computer-mediated technology and social interaction. C. A. Lin and D. J. Atkin (eds.), Communication, technology and social change. Theory and implications. London: LEA Publishers.

Cardon, D. and Granjon, F. (2010). Médiactivistes. Paris: Les Presses de Sciences Po.

Charaudeau, P. (2005). Le discours politique. Les masques du pouvoir. Paris: Vuibert.

CONATEL (2016). Tableau de bord du secteur de la téléphonie mobile. Statistiques des Télécommunications. http://www.conatel.gouv.ht/sites/default/files/ TABLEAU_DE_BORD\%20\%281\%29.pdf. 25 October 2020.

Creswell, J.W. (2012). Educational research: planning, conducting, and evaluating quantitative and qualitative research. Boston, MA: Pearson. 
Dahlber-Grundberg, M. (2016). Digital media and the transnationalization of protests (Unpublished Ph.D. thesis). Umea University, Sweden. https://umu.divaportal.org/smash/get/diva2:895571/FULLTEXT01.pdf.

Fuchs, C. (2012). The political economy of privacy on Facebook. Television \& New Media, 13(2), 139-159. doi:10.1177/1527476411415699.

Fuchs, C. (2014). Social media: A critical introduction. London: SAGE Publications.

Garnham, N. (1990). Capitalism and communication: Global culture and the economics of information. London: SAGE Publications.

Giroux, S. and Tremblay, G. (2009). Méthodologies des sciences humaines. La recherche en action. Québec: Renouveau pédagogique.

Gonzáles, L. A. G. (2016). New social movements and social networking sites' uses: Mexicans' mobilization for peace in Mexico (Unpublished Ph.D. thesis). Nottingham Trent University, Nottingham. https://core.ac.uk/download/pdf/46664584.pdf.

Habermas, J. (1989). The structural transformation of the public sphere. Cambridge, MA: MIT Press.

(1997). L'espace public: Archéologie de la publicité comme dimension constitutive de la société bourgeoisea. (M. Buhot, trans.). Launey, Paris: Payot.

(2006). Political communication in media and society: Does democracy still enjoy an epistemic dimension? The impact of normative theory on empirical research. Communication Theory, 16, 411-426. doi:10.1111/j.14682885.2006.00280.x.

Herman, E. S. and Chomsky, N. (1988). Manufacturing consent. The political economy of the mass media. New York: Pantheon Books. https://www.marxists. org/archive/marx/works/download/Marx_Contribution_to_the_Critique_of_ Political_Economy.pdf.

Johannessen, M. R. (2012). Social media as public sphere. An exploratory study of online political communication in Norway (Unpublished Ph.D. thesis). University of Adger, Kristiansand. https://uia.brage.unit.no/uia-xmlui/handle/11250/139746.

Kaplan, A. M. (2014). Social media, definition and history. R. Alhaji and J. Rokne (eds.), Encyclopedia of social network analysis and mining. New York: Springer.

Marx, K. (1970). A contribution to the critique of political economy. Moscow: Progress Publishers.

Miège, B. (2004). L'économie politique de la communication. Hermès, La Revue, 1(38), 46-54.

Mosco, V. (2009). The political economy of communication. London: SAGE.

Morozov, E. (2009). The brave new world of slacktivism. Foreign Policy. http:// neteffect.foreignpolicy.com/posts/2009/05/19/the_brave_new_world_of_ slacktivism. 18 February 2021.

Murdock, G. and Golding, P. (1973). For a political economy of mass communication.

$106 \mid$ ETKíteşim | Yıl 4 |Sayı 8 |Ekim 2021 
Socialist Register, 10, 205-234.

Pierre-Louis, L. R. (2012). Communication et espace public. Une reconstruction à travers l'espace public politique haïtien. Louvan-la-Neuve: Presses Universitaires de Louvain.

Van Dijk, T. A. (1993). Principles of critical discourse analysis. Discourse \& Society, 4(2), 249-283.

Wasko, J. (2014). The study of the political economy of the media in the twentyfirst century. International Journal of Media and Cultural Politics, 10(3), 259-271. doi: 10.1386/macp.10.3.259_1.

Wittel, A. (2012). Digital Marx: Toward a political economy of distributed media. TripleC, 10(2), 313-333.

Ethics committee approval: There is no need for ethics committee approval.

Conflict of interest: There are no conflicts of interest to declare.

Financial support: No funding was received for this study.

Author Contribution Rate: Marc-Henry PIERRE (50\%), Mehmet GÜZEL (50\%).

Etik Kurul Onayı: Etik kurul onayına ihtiyaç bulunmamaktadır.

Çıkar çatışması: Çıkar çatışması bulunmamaktadır.

Finansal destek: Finansal destek bulunmamaktadır.

Yazar katkı oranı: Marc-Henry PIERRE (\%50), Mehmet GÜZEL (\%50). 